\section{Compost and Black Polyethylene Mulches Improve Spring Production of Romaine Lettuce in Southern New England}

\author{
Rahmatallah Gheshm ${ }^{1}$ and Rebecca Nelson Brown ${ }^{1}$
}

AdDITIONAL INDEX WORDs. Lactuca sativa, northeastern United States, shredded leaf, soil temperature

SUMMARY. Romaine lettuce (Lactuca sativa) is the most popular leafy vegetable in the United States. Organic and synthetic mulch materials are applied by farmers to reduce their weeding expenditures, manage soil temperatures, and increase the yield and quality of their crops. This study examined the impacts of using black polyethylene, compost, and shredded leaves as surface mulches in spring open field romaine lettuce by using data regarding the soil temperature, lettuce growth, and yield parameters. Mulch treatments were compared to determine effects on soil temperature, lettuce growth rates, leaf area index (LAI), yield, and plant size. Experiments were conducted in 2017 and 2019. Soil temperatures were slightly (but significantly) warmer in 2019, the plants grew more rapidly, and LAI, yield, and plant size were all significantly greater than they were in 2017 . Mean soil temperatures were 18.0 and $18.9^{\circ} \mathrm{C}$ in black polyethylene mulched plots, 17.7 and $18.5{ }^{\circ} \mathrm{C}$ in compost, 17.5 and $17.0^{\circ} \mathrm{C}$ in bare ground, and 16.9 and $17.3^{\circ} \mathrm{C}$ in shredded leaf plots in 2017 and 2019, respectively. Changes in canopy size presented a similar trend over the growing season for all treatments; shredded leaf and bare ground treatments on all measuring dates had the smallest canopy size, and compost and black polyethylene mulches had the largest canopy sizes. Black polyethylene and compost mulches had the highest LAI and yields in both years. In 2017, the bare ground treatment was similar to black polyethylene and compost mulch treatments for both parameters, and all three treatments were significantly greater than the shredded leaf mulch treatment. In 2019, the bare ground treatment was similar to the shredded leaf mulch treatment and significantly lower than the black polyethylene and compost mulch treatments. In 2017 , black polyethylene and compost mulches had LAI of 7.67 and 7.37 and yields of 6.38 and $6.68 \mathrm{~kg} \cdot \mathrm{m}^{-2}$, respectively. Bare ground had an LAI of 7.16 and yielded $5.94 \mathrm{~kg} \cdot \mathrm{m}^{-2}$. Shredded leaf mulch plots had the lowest LAI (5.94) and yield $\left(4.96 \mathrm{~kg} \cdot \mathrm{m}^{-2}\right)$. In 2019 , the bare ground treatment had an LAI of 7.5 and yielded $7.6 \mathrm{~kg} \cdot \mathrm{m}^{-2}$. Black polyethylene and compost mulches increased LAI by 1.7 . Yield increased by $2.8 \mathrm{~kg} \cdot \mathrm{m}^{-2}$ with black polyethylene mulch and by $2.4 \mathrm{~kg} \cdot \mathrm{m}^{-2}$ with compost mulch. Shredded leaf mulch produced LAI and yield similar to but slightly lower than bare ground. Dry weight, plant height, and head diameter in bare ground and shredded leaf mulch treatments were significantly smaller than in black polyethylene and compost mulch treatments. The cultivar rank order was consistent across treatments in both years; 'Ridgeline' grew significantly faster than 'Coastal Star', and plants were significantly larger at harvest. Black polyethylene suppresses weeds and increases soil temperatures, thereby enhancing yields of spring-to-summer romaine lettuce under southern New England conditions. Compost mulch has similar effects on yields. Shredded leaf mulch is effective at suppressing weeds but decreases soil temperatures and yields.
$\mathrm{R}$ omaine lettuce (Lactuca sat$i v a)$ is one of the most important fresh market vegetable crops in the United States. The annual lettuce consumption in 2017 was 24.5 lb per person, of which $45 \%$ (11 lb per person) were romaine and leaf lettuce. Ninety-five percent of the romaine lettuce consumed in the United States is grown in the United States, primarily in California and Arizona [U.S. Department of Agriculture (USDA), 2019]. The cost of shipping by refrigerated truck for distances between 1501 to 2500 miles in the second quarter of 2018 was $\$ 2.45$ per mile (USDA, 2018); transporting a load of lettuce from California to New England costs more than $\$ 6000$. Due to the high cost and environmental impact of shipping, loss of freshness, and desire for fresh and healthy foods, the demand for local produce is increasing rapidly in New England.

Generally, lettuce is considered a cool-season crop with an optimum production temperature of $23{ }^{\circ} \mathrm{C}$ during the day and $7{ }^{\circ} \mathrm{C}$ at night, while $28 / 12^{\circ} \mathrm{C}$ day/night or higher can cause bolting, bitterness, tip burn, and poor heading (Jackson et al., 1996). Lettuce is particularly sensitive to root zone temperatures and can tolerate higher than optimum air temperatures if the temperatures in the soil or rooting media are optimal (Jie and Kong, 1998). New England has cool spring and summer temperatures suitable for lettuce production. Lettuce can be harvested from outdoor plantings in Rhode Island from May through October, making it a good crop for local markets.

Farmers commonly use black plastic mulch to increase the yield and quality of vegetable crops (DoVale
Received for publication 18 Feb. 2020. Accepted for publication 10 May 2020.

Published online 18 June 2020.

${ }^{1}$ Department of Plant Sciences and Entomology, University of Rhode Island, Kingston, RI 02881

We acknowledge Rhode Island Agricultural Experiment Station for their support and thank Timothy Sherman for help with fieldwork.

R.G. is a Postdoctoral Fellow.

R.N.B. is the corresponding author. E-mail: brownreb@ uri.edu.

This is an open access article distributed under the CC BY-NC-ND license (https://creativecommons.org/ licenses/by-nc-nd/4.0/).

https://doi.org/10.21273/HORTTECH04594-20

\begin{tabular}{llll}
\hline $\begin{array}{l}\text { Units } \\
\begin{array}{l}\text { To convert U.S. to SI, } \\
\text { multiply by }\end{array}\end{array}$ & U.S. unit & SI unit & $\begin{array}{l}\text { To convert SI to U.S., } \\
\text { multiply by }\end{array}$ \\
\hline 0.3048 & $\mathrm{ft}$ & $\mathrm{m}$ & 3.2808 \\
0.0929 & $\mathrm{ft}^{2}$ & $\mathrm{~m}^{2}$ & 10.7639 \\
0.0283 & $\mathrm{ft}^{3}$ & $\mathrm{~m}^{3}$ & 35.3147 \\
3.7854 & $\mathrm{gal}$ & $\mathrm{L}$ & 0.2642 \\
2.54 & inch(es $)$ & $\mathrm{cm}^{3}$ & 0.3937 \\
16.3871 & inch & $\mathrm{cm}$ & 0.0610 \\
0.0418 & langley(s) & $\mathrm{MJ} \cdot \mathrm{m}^{-2}$ & 23.9006 \\
0.4536 & $\mathrm{lb}$ & $\mathrm{kg}$ & 2.2046 \\
1.1209 & $\mathrm{lb} / \mathrm{acre}$ & $\mathrm{kg} \cdot \mathrm{ha}^{-1}$ & 0.8922 \\
4.8824 & $\mathrm{lb} / \mathrm{ft}^{2}$ & $\mathrm{~kg} \cdot \mathrm{m}^{-2}$ & 0.2048 \\
0.0254 & $\mathrm{mil}(\mathrm{s})$ & $\mathrm{mm}$ & 39.3701 \\
1.6093 & $\mathrm{mile}(\mathrm{s})$ & $\mathrm{km}$ & 0.6214 \\
$\left({ }^{\circ} \mathrm{F}-32\right) \div 1.8$ & ${ }^{\circ} \mathrm{F}$ & ${ }^{\circ} \mathrm{C}$ & $\left({ }^{\circ} \mathrm{C} \times 1.8\right)+32$
\end{tabular}

Hortlechnology $\cdot$ August $202030(4)$ 
and Medeiros, 2012). Black polyethylene mulch is known to increase soil temperatures (Tarara, 2000) and decrease weed competition (Lamont, 1993). Nutrient availability often increases under black polyethylene mulch as it prevents leaching and accelerates mineralization of soil organic matter (Lamont, 1993; Steinmetz et al., 2016). Plastic mulch has been shown to increase soil moisture in irrigated production systems by decreasing evaporation from the soil surface (Lamont, 1993), but it can decrease soil moisture in rainfed systems by inhibiting the penetration of rainfall (Schonbeck and Evanylo, 1998a). However, the impact of plastic mulching on the environment is a critical issue. Worldwide, plastic mulch consumption on farms has increased dramatically in recent decades (Kasirajan and Ngouajio, 2012). Few recycling facilities will accept plastic mulch because it is contaminated with soil and agricultural chemicals (Steinmetz et al., 2016); therefore, most plastic mulch is disposed of in landfills. Many small-scale and organic farmers opt not to use plastic mulch because of disposal problems and concerns about soil contamination from partially degradable plastic mulches (Cowan et al., 2013; Kasirajan and Ngouajio, 2012).

Many organic materials can be used as mulching materials to control weeds. Organic mulches can improve soil quality, structure, and nutrients over time by increasing soil organic matter (Sinkevičienè et al., 2009). They increase soil moisture in both irrigated and rain-fed systems by reducing surface evaporation (Schonbeck and Evanylo, 1998a). Effects of organic mulches on soil temperatures vary depending on the material used as mulch, the soil type, and the season. A 3-inch-thick mulch of oak (Quercus sp.) and maple (Acer sp.) leaves reduced soil temperature by $10^{\circ} \mathrm{F}$ relative to bare soil during the summer in Connecticut (Hill et al., 1982). Numerous other studies have reported that mulching with coarse organic materials such as straw, hay, shredded newspaper, pine (Pinus sp.) needles, and bark mulch reduces soil temperatures, particularly in the spring (Munn, 1992; Schonbeck and Evanylo, 1998a; Sinkevičienè et al., 2009; Skroch et al., 1992). Gheshm and Brown (2018) reported that a 1-inch-thick layer of multisource compost applied to soil in a high tunnel in Rhode Island increased soil temperatures relative to bare soil during fall lettuce production but had no effect on average soil temperature during the spring. Schonbeck and Evanylo (1998a) reported that soil temperatures in plots mulched with dark-colored hardwood leaf compost were an average of $1.4^{\circ} \mathrm{C}$ cooler than soil temperatures in bare ground plots. Pinamonti (1998) reported that two mixed-source composts used as mulch in a vineyard in Italy increased soil temperature relative to bare ground in June and September but decreased soil temperature in July and August. In Florida, various dark colored mixed-source composts are used in increased soil temperatures relative to white-on-black plastic mulch; no bare ground treatment was used (Roe et al., 1993).

All mulch materials provide benefits and have negative effects; farmers must weigh these factors when selecting a mulch material. In southern New England, the soil-warming properties of black polyethylene mulch and ease of mechanical application are attractive, but negative environmental effects and cost of disposal of plastic mulch may outweigh the benefits for lettuce. Organic mulches can be incorporated at the end of the growing season to add organic matter to the soil. Both leaves and compost can be spread with manure spreaders, thus reducing labor costs (Roe et al., 1993). Compost has been extensively researched as a mulching material; however, in peri-urban areas, competition from homeowners and landscapers drives the cost of finished compost higher than what many farmers can afford. Hardwood leaves are a popular mulching material on peri-urban farms in New England because the leaves are available free of charge from local yard care services. However, leaves have been reported to significantly slow soil warming in the spring in New England (Hill et al., 1982). The objective of this study was to compare compost and shredded leaves as mulching alternatives for spring romaine lettuce production in southern New England. Bare ground was included as a control, and all treatments were compared with black polyethylene mulch because it is the most widely used mulching material in vegetable production.

\section{Materials and methods}

LOCATION, DATES, AND EDAPHIC AND WEATHER CONDITIONS. The experiment was conducted as late spring plantings in 2017 and 2019 at the University of Rhode Island's Gardiner Crops Research Center in Kingston (lat. $41^{\circ} \mathrm{N}$, long. $71^{\circ} \mathrm{W}$ ). In 2017, the transplanting date was 5 May, and lettuce was harvested on 6 July. In 2019, seedlings were transplanted to the experimental plots on 29 Apr., and lettuce was harvested on 26 June. The field soil is sandy loam, with a $\mathrm{pH}$ of 5.9 and $3.6 \%$ organic matter. The air temperatures during the 2017 growing season ranged from a minimum of $6.9^{\circ} \mathrm{C}$ in May to a maximum of $26.6^{\circ} \mathrm{C}$ in June. In 2019, air temperatures during the study ranged from $3.3{ }^{\circ} \mathrm{C}$ in May to $31.1^{\circ} \mathrm{C}$ in June. The mean air temperatures for the growing season were $18.5^{\circ} \mathrm{C}$ in 2017 and $16.7^{\circ} \mathrm{C}$ in 2019 . Cumulative solar radiation during the experiment was $1197 \mathrm{MJ} \cdot \mathrm{m}^{-2} \cdot \mathrm{d}^{-1}$ in 2017 and $1069 \mathrm{MJ} \cdot \mathrm{m}^{-2} \cdot \mathrm{d}^{-1}$ in 2019. Precipitation during the experiment totaled 7.1 inches in 2017 and 8.23 inches in 2019.

Crop PRODUCTION METHODS. On 23 Mar. 2017 and 21 Mar. 2019 , seeds of two full-size romaine lettuce cultivars, Ridgeline and Coastal Star, were seeded into 102cell plug trays with a cell volume of 22 $\mathrm{cm}^{3}$ (Landmark Plastics, Akron, $\mathrm{OH}$ ) filled with a bark and peatmoss-based greenhouse medium with starter nutrients (Metromix 510; Sun Gro Horticulture, Agawam, MA). 'Ridgeline' is best suited for spring and autumn production. 'Coastal Star' is a heattolerant cultivar developed for organic production systems. Seeds of these cultivars were obtained from Johnny's Selected Seeds (Albion, ME). In 2017, the planted trays were kept for $10 \mathrm{~d}$ in the greenhouse at $25^{\circ} \mathrm{C}$; then, transplants were grown in the high tunnel for $30 \mathrm{~d}$. In 2019 , seedlings were grown in the greenhouse at $25^{\circ} \mathrm{C}$ for $30 \mathrm{~d}$ and hardened outdoors for $7 \mathrm{~d}$ before transplanting. On 5 May 2017 and 29 Apr. 2019, plants were transplanted to raised beds. Beds were $115 \mathrm{ft}$ long, 30 inches wide, and 7 inches high, and were a nominal $5 \mathrm{ft}$ apart on center. 
Before making raised beds, fertilizers were broadcast and incorporated in the soil to provide $96 \mathrm{lb} /$ acre nitrogen $(\mathrm{N}), 35 \mathrm{lb} /$ acre phosphorus $(\mathrm{P})$, and $58 \mathrm{lb} /$ acre potassium (K). Each bed had two lines of drip tape with 12 -inch emitter spacing and a 0.25 $\mathrm{gal} / \mathrm{h}$ flow rate (Chapin BTF; Jain Irrigation, Watertown, NY) and was spaced 10 inches apart underneath the mulch. In 2017, the field was irrigated four times for $6 \mathrm{~h}$ each time. A total of $18.5 \mathrm{~m}^{3}$ of water was applied. In 2019, the field was irrigated three times for $6 \mathrm{~h}$ each time, and the total volume of water was $13.9 \mathrm{~m}^{3}$. Soil temperature data $\log$ gers were placed between plants in the center of each subplot at 2 inches below the soil surface. Air temperature loggers were installed at 10 inches above the surface in one subplot per replication. In 2017, the data loggers were iButton units (Maxim Integrated, San Jose, CA); in 2019, they were RC-51H units (Elitech Technology, Milpitas, CA). Air and soil temperatures were recorded at 4$\mathrm{h}$ intervals. Plants were irrigated immediately after transplanting and as needed during growth. Experimental plots in 2017 were fertigated on 12 and 23 May. In 2019, fertigation was conducted on 24 May and 5 June. During both years, a water-soluble fertilizer (Aquatrols, Paulsboro, NJ) was used to provide $25.3 \mathrm{lb} /$ acre $\mathrm{N}$, $9.0 \mathrm{lb} /$ acre $\mathrm{P}$, and $18.9 \mathrm{lb} /$ acre $\mathrm{K}$.

EXPERIMENTAL DESIGN AND MULCHING MATERIALS. Our experimental design was a split plot with four replications. Mulch treatments were applied to the main plots and cultivars were applied to subplots. The main plots were $8 \mathrm{~m}$ long; subplots were $4 \mathrm{~m}$ long and $0.75 \mathrm{~m}$ wide. Each plot had two rows of lettuce 40 $\mathrm{cm}$ apart. In-row spacing between plants was $30 \mathrm{~cm}\left(8.3\right.$ plants $\left./ \mathrm{m}^{2}\right)$. The main plots were separated by an unplanted buffer $60 \mathrm{~cm}$ long, and the entire experiment was surrounded by a buffer planted to romaine lettuce. Main plot treatments were bare ground, compost mulch, black polyethylene mulch, and shredded leaf mulch. The compost was produced from a mixture of feedstocks (animal manure, wood chips, leaves, fish scraps, shellfish waste, seaweed, spent mushroom substrate, food scraps, coffee grounds, and wood ash) in outdoor-turned windrows using an 18-month process (Earth Care Farm, Charlestown, RI). The nutrient content of oven-dried compost was estimated at $1.3 \% \mathrm{~N}, 0.11 \% \mathrm{P}$, and $1.0 \%$ $\mathrm{K}$ in 2017; in 2019, the content was estimated at $1.0 \% \mathrm{~N}, 0.08 \% \mathrm{P}$, and $0.12 \% \mathrm{~K}$. Locally sourced deciduous tree leaves collected in Autumn 2016 and Autumn 2018 and stored outdoors in uncovered piles were airdried and shredded to make shredded leaf mulch. Both compost and shredded leaf mulches were applied to a depth of 2 inches. Both low-nutrient composts such as the one used in this study and aged deciduous tree leaves have been shown to have minimal effects on soil nutrient status when used as a short-duration surface mulch (Schonbeck and Evanylo, 1998b; Valenzuela-Solano and Crohn, 2006). Standard 1.0-mil micro-embossed black polyethylene mulch (Berry Plastics, Evansville, IN) was laid using a mulch layer (2550; Rain-Flo Irrigation, East Earl, PA). In both years, weeds in the bare ground plots were controlled by hand. Bare ground plots were weeded on 11 and 24 May 2017, 20 May 2019, and 3 June in 2019. Alleys and buffers were mulched with locally sourced aged wood chips in 2017. In 2019, landscape fabric (UltraWeb 3000; Dewitt, Sikeston, MO) was used to prevent weeds in alleys.

Data COllection methods. Data regarding canopy size, yield, leaf area index, plant height, and plant dry weight (shoot only) were collected. Canopy size was calculated using a variance of the method of Bumgarner at al. (2012). Every $10 \mathrm{~d}$ during vegetative growth $(7$ May to 19 June 2017 and 29 Apr. to 20 June 2019), digital images were obtained using a white quadrat $(35 \times 35 \mathrm{~cm})$ placed around two randomly selected plants in the middle of each subplot. Images were obtained from a height of $60 \mathrm{~cm}$ above the quadrat, perpendicular to the ground. The percentage of the green cover was calculated using Caneopeo (Patrignani and Ochsner, 2015) and converted to an area based on the quadrat area. Lettuce was harvested at the final stage of head development on 6 July 2017 and 26 June 2019. Leaf area was measured for two marketable plants randomly selected at harvest time. The leaves were stripped from the stem and spread in a single layer inside a $1-\mathrm{m}^{2}$ quadrat; leaf area was measured using digital imagery and Caneopeo. The leaf area index (LAI) was calculated from the measured leaf area for each plant. To measure dry weight, leaves were cut into small pieces and dried in a $43{ }^{\circ} \mathrm{C}$ oven until there was no change in weight.

Data ANalysis. Single measures data were analyzed using PROC GLM analysis of variance (ANOVA) and Duncan's multiple range tests in SAS (version 9.4; SAS Institute, Cary, $\mathrm{NC}$ ). Growth rate and soil temperature data were analyzed using PROC MIXED multivariate repeated-measures ANOVA with year, cultivar, and mulch as fixed effects, block as a random effect, and date as the repeated effect. Compound symmetry covariance was used with the repeated effect when analyzing the growth rate to address structured unequal variance across dates. Levene's test for homogeneity of variance was used to compare variances across mulch treatments for soil temperatures. Graphs were created using the software packages Microsoft Office Excel (version 2016; Microsoft Corp., Redmond, WA) and Veusz 3.1 (Sanders, 2019).

\section{Results and discussion}

EFFECTS OF YEAR. The year effect was significant for all measurements. This was expected because weather conditions vary widely from year to year in southern New England. The year $\times$ mulch effect was significant for soil temperature, canopy size, LAI, and yield; therefore, results are presented by year below. The year $x$ cultivar effect was not significant. Plants were larger in 2019 than in 2017 for all parameters measured (Table 1). Growth occurred significantly faster in 2019 than in 2017, particularly during the first $30 \mathrm{~d}$ after transplanting (Fig. 1)

EFFECTS OF MULCH TYPE ON SOIL TEMPERATURES. Mulch treatment effected both the mean soil temperature and diurnal fluctuation in soil temperature. In 2017, mean root zone soil temperatures ranged from $16.9^{\circ} \mathrm{C}$ in plots with shredded leaf mulch to $18.0^{\circ} \mathrm{C}$ in plots with black polyethylene mulch (Table 2). Variance ranged from 19.5 in the black polyethylene mulch treatment to 13.6 in the shredded leaf mulch treatment. Black polyethylene and 
Table 1. Effects of year on soil temperature, leaf area index (LAI), dry weight, plant height, and head diameter across all mulch treatments and two romaine lettuce cultivars.

\begin{tabular}{|c|c|c|c|c|c|c|}
\hline \multirow[b]{2}{*}{ Yr } & \multirow{2}{*}{$\frac{\text { Soil temp }}{\left({ }^{\circ} \mathbf{C}\right)^{\mathrm{z}}}$} & \multirow[b]{2}{*}{ LAI } & Yield & Dry wt & Plant ht & Head diam \\
\hline & & & \multicolumn{2}{|c|}{$\left(\mathrm{kg} \cdot \mathrm{m}^{-2}\right)^{\mathrm{z}}$} & \multicolumn{2}{|c|}{$\begin{array}{l}(\mathrm{cm})^{\mathrm{z}} \\
\end{array}$} \\
\hline 2017 & 17.4 & 7.0 & 6.0 & 0.265 & 33.6 & 19.5 \\
\hline 2019 & 17.9 & 8.3 & 8.9 & 0.353 & 39.5 & 29.2 \\
\hline$P$ & 0.012 & $<0.0001$ & $<0.0001$ & $<0.0001$ & $<0.0001$ & $<0.0001$ \\
\hline
\end{tabular}

${ }^{\mathrm{z}}\left(1.8 \times{ }^{\circ} \mathrm{C}\right)+32={ }^{\circ} \mathrm{F}, \mathrm{l} \mathrm{kg} \cdot \mathrm{m}^{-2}=0.2048 \mathrm{lb} / \mathrm{ft}^{2}, \mathrm{l} \mathrm{cm}=0.3937$ inch.

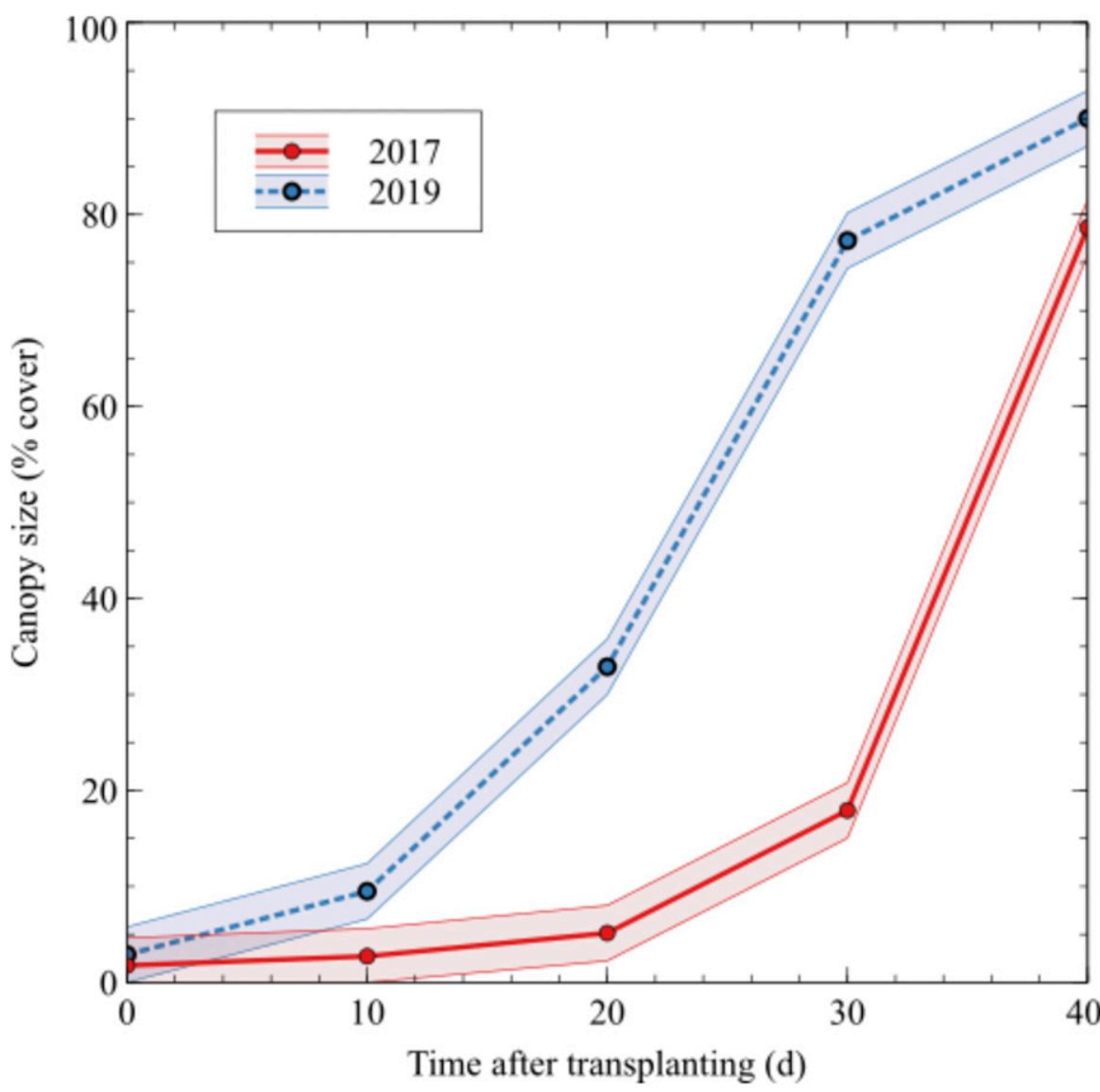

Fig. 1. Differences in plant growth between years, measured as the change in canopy size over time since transplanting, for romaine lettuce grown in the field in Rhode Island. In 2017, transplanting occurred on 7 May; in 2019, transplanting occurred on 29 Apr. Data are averages of 32 subplots per year. Soil temperature was $0.54{ }^{\circ} \mathrm{C}\left(0.972{ }^{\circ} \mathrm{F}\right)$ higher in 2019 . Shaded bands indicate $95 \%$ confidence intervals around the least means square values $(P<0.0001)$.

compost mulches resulted in similar mean soil temperatures, but plots with compost mulch had significantly $(P<0.001)$ lower variations near the mean. Shredded leaf mulch had the greatest ability to moderate soil temperature changes, resulting in both the lowest mean soil temperature $\left(16.9^{\circ} \mathrm{C}\right)$ and significantly $(P<0.0001)$ lower variance. Mean soil temperature in the bare ground plots was similar to that of all other treatments, and variance was similar to that in plots mulched with black polyethylene.

As in 2017, mean root zone soil temperatures in 2019 were significantly $(P<0.01)$ different between plots, ranging from $17.0^{\circ} \mathrm{C}$ in the bare ground plots to $18.9^{\circ} \mathrm{C}$ in plots with black polyethylene mulch (Table 2 ). The black polyethylene and compost treatments were significantly warmer than the bare ground and leaf mulch treatments. Interestingly, in 2019, the black polyethylene and compost mulch treatments also had similar variance, with the variance in the black polyethylene mulched plots being significantly $(P=0.002)$ lower than that in the bare ground plots. The bare ground treatment had the highest variance in 2019. As in 2017, the shredded leaf mulch resulted in significantly lower variance than any of the other treatments $(P<0.0001)$.

Both mean root zone temperature and variance were similar across years in the bare ground and treatment. Mean root zone temperature was similar across years in the shredded leaf mulch treatment, but variance was significantly $(P<0.0001)$ lower in 2019 than in 2017. In contrast, the mean root zone temperatures were significantly $(P<0.05)$ higher in 2019 than in 2017 in the compost and black polyethylene mulch treatments, and variance was lower. Average air temperatures during the experiment in 2019 were $1.8{ }^{\circ} \mathrm{C}$ cooler than in 2017 , and conditions were wetter, which would be expected to decrease soil temperatures. In fact, the mean soil temperature in the bare ground treatment was slightly lower in 2019 , although the difference was not statistically significant. However, soil temperatures increased in the mulched treatments and when means were compared by years across all treatments (Table 1). This may be due to the use of black landscape fabric between beds rather than light-colored wood chips (Fig. 2). The landscape fabric likely raised temperatures in the alleys on sunny days, whereas the woodchips likely acted as an insulating layer, suppressing soil warming in the alleys.

Overall, the mean temperatures of the soil in the plastic mulch and compost treatments were warmer than in the shredded leaf and bare ground treatments, suggesting that the dark-colored compost absorbed solar radiation like the plastic mulch (Fig. 3). Kamal and Singh (2011) and Schonbeck and Evanylo (1998a) similarly reported that the highest soil temperatures occurred under black polyethylene mulch in their experiments. Schonbeck and Evanylo (1998a) reported that black paper mulch and dark-colored compost mulch both increased soil temperatures in the 
Table 2. The effect of mulch type on soil temperature at a depth of 2 inches $(5.1 \mathrm{~cm})$ below the soil surface in 2017 and 2019 . The treatment $\times$ year interaction was significant $(P=\mathbf{0 . 0 3 2})$.

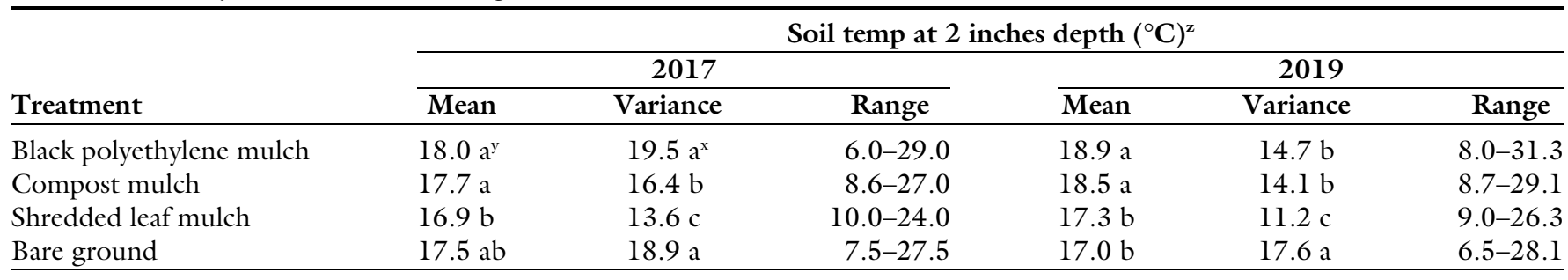

${ }^{\mathrm{z}}\left(1.8 \times{ }^{\circ} \mathrm{C}\right)+32={ }^{\circ} \mathrm{F}$.

${ }^{y}$ Mean separation in columns by differences of paired least squares means at $P \leq 0.05$

'Variance separation in columns by Levene's test for homogeneity of variance at $P \leq 0.05$.
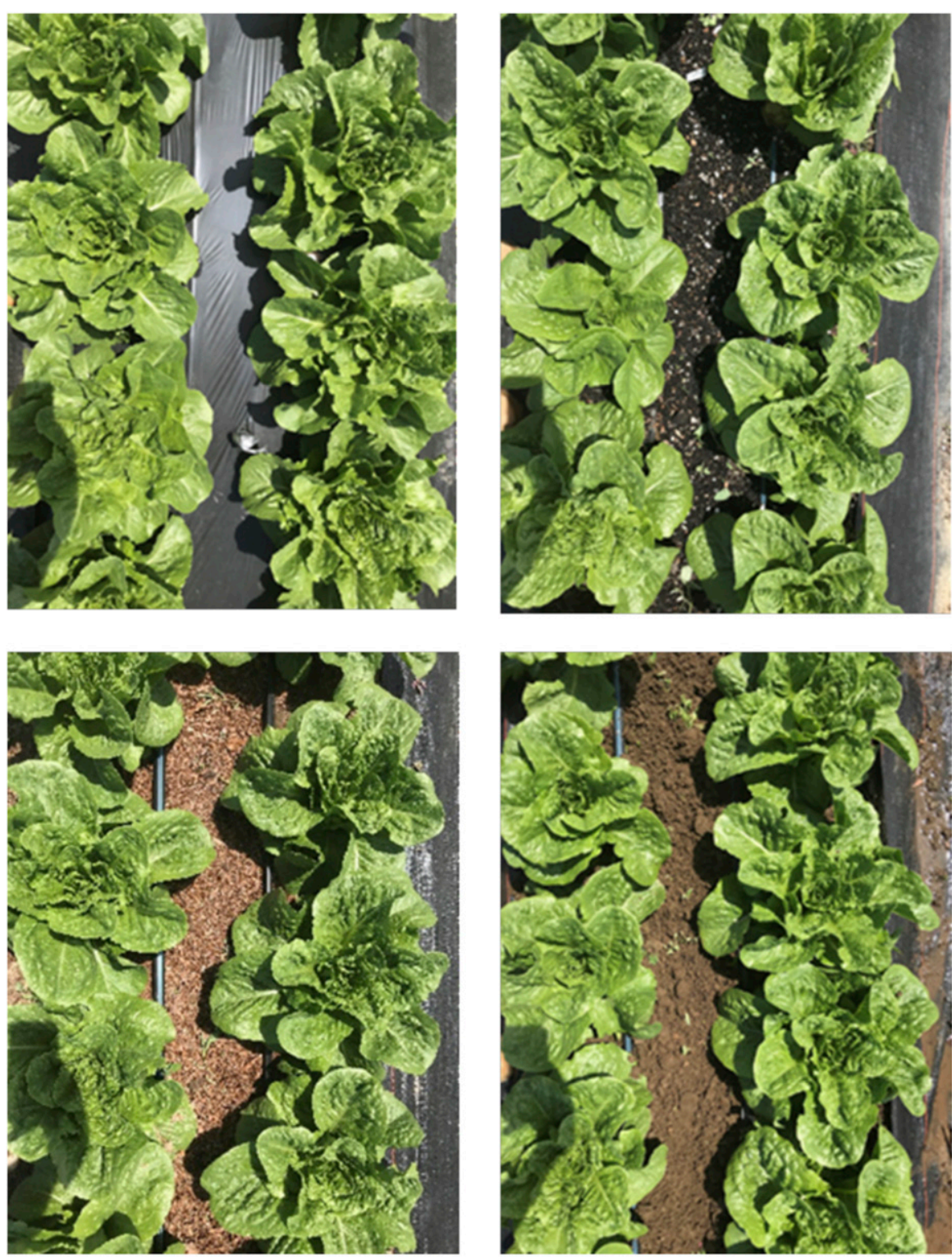

Fig. 2. Two romaine lettuce cultivars, Ridgeline and Coastal Star, grown as a spring-to-summer crop in Rhode Island in black polyethylene mulch (top, left), compost mulch (top, right), shredded leaf mulch (bottom, left), and bare ground (bottom, right) on raised beds in 2019.

morning but decreased them in the afternoon relative to bare ground. The narrower range and lower variance for shredded leaf mulch (Table
2) suggest that the mulch reduced absorption of solar radiation during the day and radiative heat loss from the soil at night. In effect, leaf mulch stabilized soil temperatures rather than altering the mean temperature. These results agree with our results of spring high tunnel romaine production (Gheshm and Brown, 2018). Other researchers have reported that organic mulch can stabilize the root zone temperatures in summer extremes and slow cooling in the fall, but note that the effect of mulching on soil temperature entirely depends on the type of mulch (Kosterna, 2014).

All types of mulches were effective for suppressing weeds; no weeds emerged in the black polyethylene and compost treatments. Some weeds emerged through the shredded leaf mulch, but there were too few to require control. The bare ground plots required hand weeding twice during the growing season.

EFFECTS OF MULCH TYPE ON LETTUCE CANOPY SIZE. The repeated measures analysis showed that there were significant differences $(P<$ 0.0001 ) among treatments in both years. Black polyethylene and compost mulches resulted in a significantly larger canopy size than bare ground and shredded leaf mulch in both years. In 2017, there was no difference between black polyethylene mulch and compost. Bare ground and shredded leaf mulch were both significantly different from all other treatments $(P<0.001)$, with canopy size larger in bare ground plots than in plots mulched with shredded leaves (Fig. 4). Forty days after transplanting in 2017 , more than $85 \%$ of the soil was covered by the lettuce canopy in both compost and black polyethylene mulch treatments. In bare ground and shredded leaf treatments, just $76 \%$ and $62 \%$ of ground area were shaded by lettuce canopy (Fig. 4). In 2019 , black polyethylene mulch and compost again resulted in similar 
canopy sizes. However, bare ground plots had a canopy size similar to that of compost plots $(P=0.13)$ and significantly larger canopies than plots mulched with shredded leaves $(P=0.04)$ (Fig. 4). Forty days after transplanting, more than $95 \%$ of the soil was covered by the canopy in the black polyethylene and compost treatments. On that date, the lettuce canopy covered $88 \%$ and $78 \%$ of the soil area with the bare ground and shredded leaf mulch treatments, respectively (Fig. 4). In 2017, shredded leaf mulch plots had the coldest root zone temperature; however, in 2019, the bare ground plots had the lowest root zone temperature (Table 2 ). The lettuce growth rate is highly correlated with both accumulated soil degree days (SDD) and accumulated photosynthetically active radiation
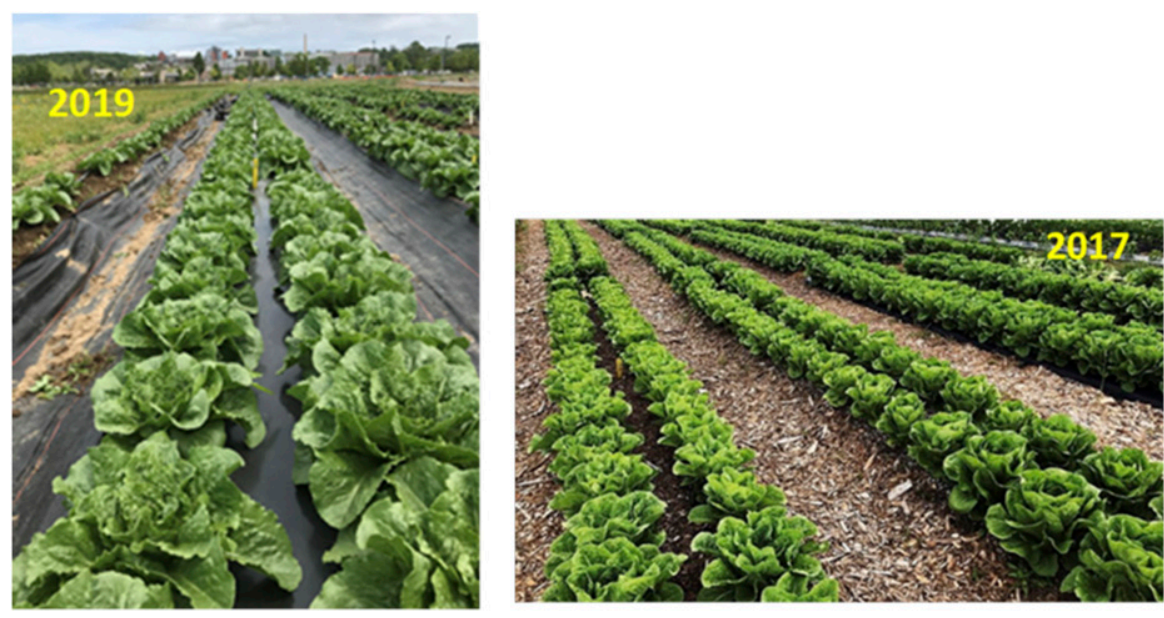

Fig. 3. The different materials used to prevent weed growth in the alleys between the raised beds used to grow romaine lettuce. In 2017, the alleys were mulched with wood chips; in 2019, black landscape fabric was used.

$(P A R)$; the growth rate is exponential, especially in the heading stage (Salomez and Hofman, 2007; Wurr et al., 1981). Higher soil temperatures accelerate leaf enlargement and development and assist the crop in reaching the maximum leaf area quickly (Dufault et al., 2009).

EFFECTS OF MULCH TYPE ON LETTUCE LEAF AREA, YIELD, AND PLANT SIZE. In 2017, shredded leaf mulch significantly $(P<0.01)$ reduced LAI relative to the other treatments. Black polyethylene mulch significantly increased leaf area over bare ground, whereas compost was similar to both black polyethylene mulch and bare ground (Table 3 ). In 2019, LAI values were similar for plots mulched with black polyethylene and with compost, and both treatments significantly $(P<0.0001)$ increased LAI over bare ground and shredded leaf mulch. (Table 3 )

In 2017, the compost treatment had the highest yields, averaging 6.68 $\mathrm{kg} \cdot \mathrm{m}^{-2}$ (Table 3 ). Black polyethylene mulch was similar at $6.38 \mathrm{~kg} \cdot \mathrm{m}^{-2}$. Plots mulched with shredded leaves had significantly $(P<0.01)$ lower yields than the other treatments, averaging only $4.96 \mathrm{~kg} \cdot \mathrm{m}^{-2}$. Bare ground yields averaged $5.94 \mathrm{~kg} \cdot \mathrm{m}^{-2}$,
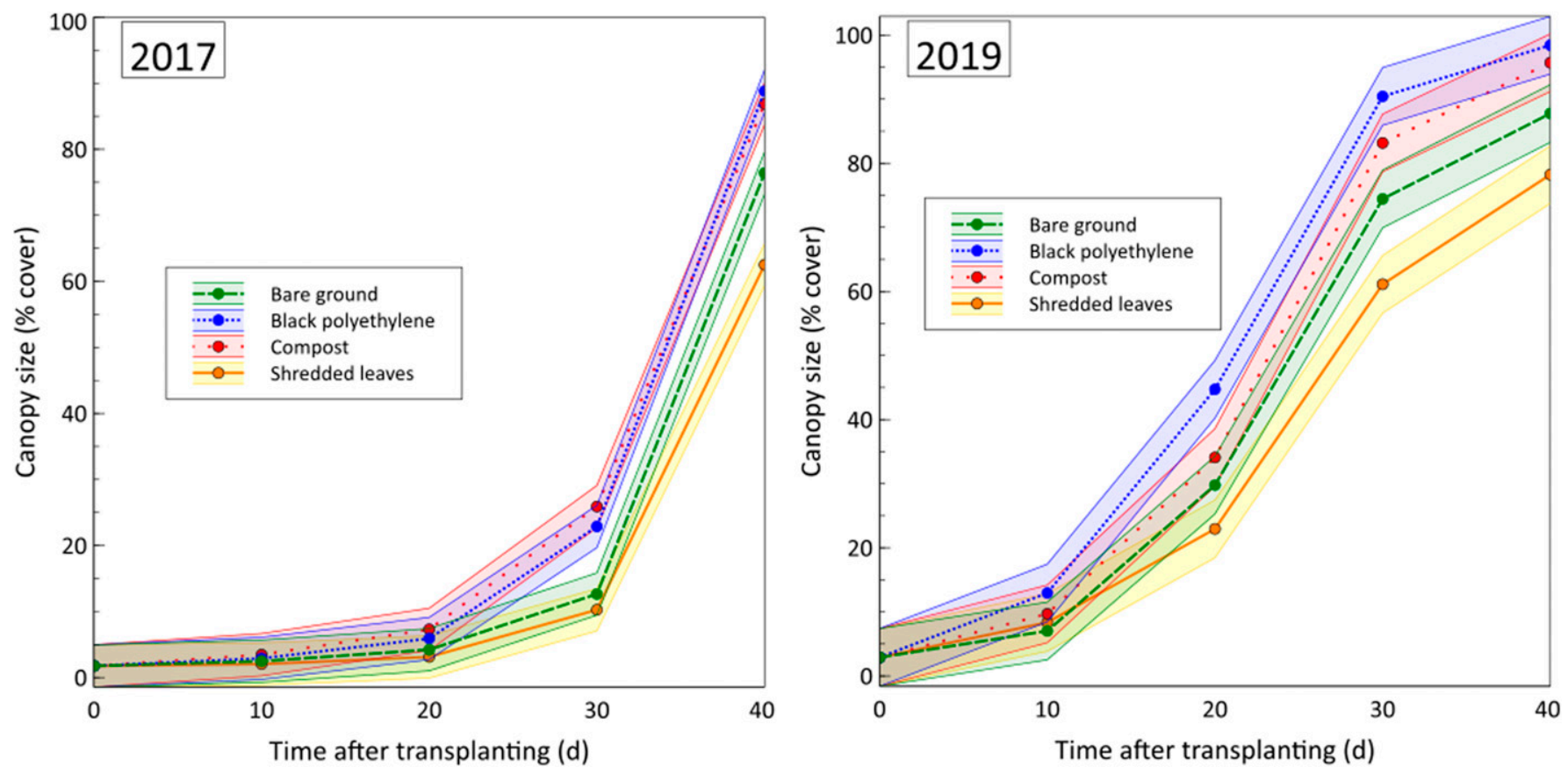

Fig. 4. Change in canopy size, measured as the percentage of covered soil area, over time for romaine lettuce in soil mulched with black polyethylene, compost, or shredded leaves or left bare. Lettuce was grown in Spring 2017 and 2019 ; data are averages of eight subplots per treatment. $P<0.0001$. Shaded bands indicate $95 \%$ confidence intervals around the least means square values. The mulch $\times$ year interaction was significant $(P=0.004)$. 


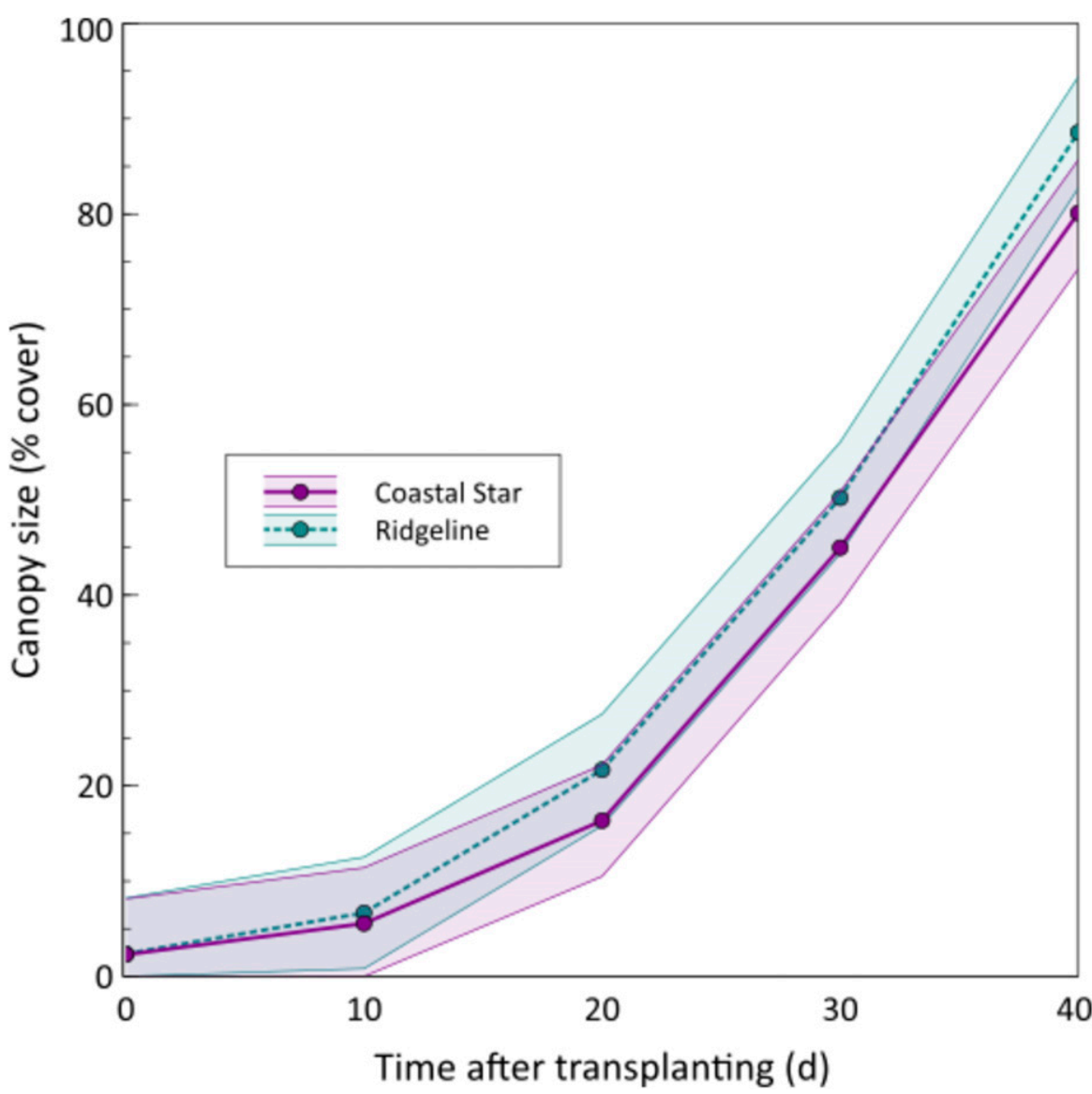

Fig. 5. Change in canopy size, measured as the percentage of covered soil area, over time for two cultivars of romaine lettuce. Lettuce was grown in Spring 2017 and 2019; data are pooled across years and are an average of 16 plots per cultivar. Cultivars were significantly different at $P=0.012$. Shaded bands indicate $95 \%$ confidence intervals around the least means square values.

Table 3. Effects of mulch type on leaf area (LAI) and yield of romaine lettuce grown in the field during Spring 2017 and Spring 2019.

\begin{tabular}{lllllr}
\hline & \multicolumn{2}{c}{ LAI } & & \multicolumn{2}{c}{ Yield $\left(\mathbf{k g} \cdot \mathbf{m}^{-2}\right)^{\mathbf{z}}$} \\
\cline { 2 - 5 } Treatment & $\mathbf{2 0 1 7}$ & $\mathbf{2 0 1 9}$ & & $\mathbf{2 0 1 7}$ & $\mathbf{2 0 1 9}$ \\
\hline Black polyethylene mulch & $7.7 \mathrm{a}^{\mathrm{y}}$ & $9.2 \mathrm{a}$ & & $6.4 \mathrm{ab}$ & $10.4 \mathrm{a}$ \\
Compost mulch & $7.4 \mathrm{ab}$ & $9.2 \mathrm{a}$ & & $6.7 \mathrm{a}$ & $10.1 \mathrm{a}$ \\
Shredded leaf mulch & $5.9 \mathrm{c}$ & $7.4 \mathrm{~b}$ & & $5.0 \mathrm{c}$ & $7.3 \mathrm{~b}$ \\
Bare ground & $7.2 \mathrm{~b}$ & $7.5 \mathrm{~b}$ & & $5.9 \mathrm{~b}$ & $7.6 \mathrm{~b}$ \\
\hline
\end{tabular}

${ }^{\mathrm{z}} 1 \mathrm{~kg} \cdot \mathrm{m}^{-2}=0.2048 \mathrm{lb} / \mathrm{ft}^{2}$.

'Mean separation in columns by Duncan's multiple range test at $P \leq 0.05$

which was significantly $(P<0.05)$ lower than the compost treatment yields but similar to that of black polyethylene yields (Table 3 ). In 2019 , the black polyethylene mulch treatment produced the highest yields, but yields in the compost treatment were similar. Both treatments significantly $(P<0.0001)$ out-yielded the bare ground and leaf mulch treatments, which were similar to each other (Table 3 ).
Data for dry weight, height, and head diameter were pooled across years because the mulch $\times$ year interactions were not significant. Plants in the compost and black polyethylene treatments averaged $0.33 \mathrm{~kg} \cdot \mathrm{m}^{-2}$ of dry matter, which was significantly $(P<0.0001)$ more than the averages of 0.29 and $0.27 \mathrm{~kg} \cdot \mathrm{m}^{-2}$ for bare ground and leaf mulch plots, respectively (Table 4). The average height for plants grown on black polyethylene mulch was $38.2 \mathrm{~cm}$, which is only 0.4 $\mathrm{cm}$ taller than plants grown with compost mulch. Both treatments were significantly $(P<0.0001)$ taller than plants grown with leaf mulch or on bare ground (Table 4). Compost mulch produced the greatest head diameter, averaging $25.25 \mathrm{~cm}$, which is slightly more than that of black polyethylene mulch. Plants in both treatments were significantly $(P<0.0001)$ larger than plants in either bare ground or shredded leaf mulch treatments. Bare ground and shredded leaf mulch were similar at 23.9 and $23.2 \mathrm{~cm}$, respectively (Table 4 ).

Cultivar effects. Cultivar effects were consistent across years, and data have been pooled. All mulch treatments affected both lettuce cultivars similarly, with no significant interaction effects. 'Ridgeline' grew significantly $(P=0.012)$ faster than 'Coastal Star', and plants were larger at harvest (Fig. 5). At the last sampling, 'Ridgeline' covered $88.6 \%$ of the plot, which is significantly $(P=$ 0.046 ) more than the $80.1 \%$ covered by 'Coastal Star' (Fig. 5). Cultivars differed significantly $(P<0.01)$ regarding dry weight, plant height, and head diameter. Yields differed significantly at $\alpha=0.1$, but not at $\alpha=0.05$ $(P=0.098)$ (Table 5). 'Ridgeline' was taller, had a larger diameter, and had a greater dry weight than 'Coastal Star'.

Vargas et al. (2017) found no interactions between mulch and cultivar in romaine lettuce for characteristics like heart diameter, shank diameter, leaf height, and leaf width. Lee et al. (2015) found a significant interaction between temperature and cultivar effects on yields of lettuce grown in high tunnels over eight seasons. However, their study included cultivars from multiple market classes and examined effects of seasonal changes in air temperature rather than mulch-induced changes in soil temperature. Lee et al. (2015) also reported a range of responses to air and soil temperatures among lettuce cultivars, which might result in differing responses to mulches.

\section{Conclusions}

The soil under dark-colored mulches (black polyethylene and compost) was warmer than soil in the unmulched bare ground plots. The use of black polyethylene 
Table 4. Effects of mulch type on dry weight, plant height, and head diameter of late spring romaine lettuce grown in the field in Rhode Island.

\begin{tabular}{lccc}
\hline & Dry wt & Plant ht & Head diam \\
\cline { 2 - 4 } Treatment & $\left(\mathrm{kg} \cdot \mathbf{m}^{-2}\right)^{\mathrm{z}}$ & & $(\mathbf{c m})^{\mathrm{z}}$ \\
\hline Black polyethylene mulch & $0.33 \mathrm{a}^{\mathrm{y}}$ & $38.2 \mathrm{a}$ & $25.0 \mathrm{a}$ \\
Compost mulch & $0.33 \mathrm{a}$ & $37.8 \mathrm{a}$ & $25.25 \mathrm{a}$ \\
Shredded leaf mulch & $0.28 \mathrm{~b}$ & $34.6 \mathrm{~b}$ & $23.2 \mathrm{~b}$ \\
Bare ground & $0.29 \mathrm{~b}$ & $35.8 \mathrm{~b}$ & $23.9 \mathrm{~b}$ \\
\hline
\end{tabular}

${ }^{\mathrm{z}} \mathrm{l} \mathrm{kg} \cdot \mathrm{m}^{-2}=0.2048 \mathrm{lb} / \mathrm{ft}^{2}, 1 \mathrm{~cm}=0.3937$ inch.

${ }^{\mathrm{x}}$ Mean separation in columns by Duncan's multiple range test at $P \leq 0.05$

Table 5. Effects of romaine lettuce cultivar on leaf area index (LAI), yield, dry weight, plant height, and head diameter in the field. Data are pooled across years.

\begin{tabular}{|c|c|c|c|c|c|}
\hline \multirow[b]{2}{*}{ Treatment } & \multirow[b]{2}{*}{ LAI } & Yield & Dry wt & Plant ht & Head diam \\
\hline & & \multicolumn{2}{|c|}{$\left(\mathrm{kg} \cdot \mathrm{m}^{-2}\right)^{\mathrm{z}}$} & \multicolumn{2}{|c|}{$(\mathrm{cm})^{\mathrm{z}}$} \\
\hline Ridgeline & 7.68 & 7.59 & 0.34 & 37.9 & 24.8 \\
\hline Coastal Star & 7.69 & 7.27 & 0.28 & 35.3 & 23.9 \\
\hline$P$ & 0.952 & 0.084 & $<0.0001$ & $<0.0001$ & 0.002 \\
\hline
\end{tabular}

${ }^{\mathrm{z}} \mathrm{l} \mathrm{kg} \cdot \mathrm{m}^{-2}=0.2048 \mathrm{lb} / \mathrm{ft}^{2}, 1 \mathrm{~cm}=0.3937$ inch.

mulch as an inorganic and compost as an organic mulch significantly increased lettuce yield. However, lighter-colored shredded leaf mulch did not increase soil temperatures or lettuce growth. Organic mulches are often reported to slow soil warming, but it appears that this may be an effect of mulch color rather than mulch thickness or the organic nature of the mulch, and that organic mulches with albedos similar to black polyethylene have a similar warming effect. Darkcolored compost offers benefits similar to those of black polyethylene for warming the soil, suppressing weeds, and enhancing lettuce growth. The increased costs of obtaining and applying compost mulch may be offset by reductions in waste and disposal costs in the current cropping season (Kasirajan and Ngouajio, 2012; Steinmetz et al., 2016). Over multiple seasons, the use of compost as a mulch (with postharvest soil incorporation) increases in soil organic matter and improves the soil structure (Kosterna, 2014; Schonbeck and Evanylo, 1998b; Steinmetz et al., 2016). Organic mulches are known to reduce soil temperatures when used during the summer (Munn, 1992; Sánchez et al., 2008), but we have shown that dark-colored organic mulch can increase soil temperature in the spring, similar to black polyethylene. Using compost instead of plastic mulch is environmentally friendly and has similar effects. Farmers who use compost instead of black polyethylene mulch in their lettuce field could enhance soil fertility by incorporating the compost after lettuce harvest.

When designing this study, we were concerned that using the dark plastic mulch could warm the soil too much in late spring, thus causing bolting or poor heading. The warming effects of mulch films are beneficial in the spring, when soil temperatures are below optimum, but could be detrimental to plant growth later in the season (Snyder et al., 2015). However, we found that dark-colored mulches were beneficial rather than detrimental when used for late spring lettuce production in coastal New England. Generally, in colder areas like New England with moderate summer conditions, black polyethylene or compost will be appropriate for spring-to-summer romaine lettuce production. Leaf mulch is not recommended for spring plantings, but it may be suitable for moderating soil temperatures in summer plantings or slowing soil cooling for fall lettuce.

\section{Literature cited}

Bumgarner, N.R., W.S. Miller, and M.D. Kleinhenz. 2012. Digital image analysis to supplement direct measures of lettuce biomass. HortTechnology 22:547-555.

Cowan, J.S., D.A. Inglis, and C.A. Miles. 2013. Deterioration of three potentially biodegradable plastic mulches before and after soil incorporation in a broccoli field production system in northwestern Washington. HortTechnology 23:849858.

DoVale, J.C. and D.C. Medeiros. 2012. Performance of lettuce cultivars to protect environmental and soil cover effects. Idesia 30:103-105.

Dufault, R.J., B. Ward, and R.L. Hassell. 2009. Dynamic relationships between field temperatures and romaine lettuce yield and head quality. Scientia Hort. 120:452-459.

Gheshm, R. and R.N. Brown. 2018. Organic mulch effects on high tunnel lettuce in southern New England. HortTechnology 28:485-491.

Hill, D.E., L. Hankin, and G.R. Stephens. 1982. Mulches: Their effect on fruit set, timing, and yields of vegetables. Connecticut Agr. Exp. Sta. Bul. 805.

Jackson, L., K. Mayberry, F. Laemmlen, S. Koike, K. Schulbach, and W. Chaney. 1996. Leaf lettuce production in California. Univ. California Div. Agr. Natural Resources Publ. 7216. 28 Sept. 2018. $<$ http://anrcatalog.ucdavis.edu/pdf/ 7216.pdf $>$.

Jie, H. and L.S. Kong. 1998. Growth and photosynthetic characteristics of lettuce (Lactuca sativa L.) under fluctuating hot ambient temperatures with the manipulation of cool root-zone temperature. J. Plant Physiol. 152:387-391.

Kamal, S. and A.K. Singh. 2011. Effect of black plastic mulch on soil temperature and tomato yield. Progress. Hort. 43: 337-339.

Kasirajan, S. and M. Ngouajio. 2012. Polyethylene and biodegradable mulches for agricultural applications: A review. Agron. Sustain. Dev. 322:501-529.

Kosterna, E. 2014. Organic mulches in the vegetable cultivation. Rev. Ecol. Chem. Eng. A 21:481-492.

Lamont, W. 1993. Plastic mulches for the production of vegetable crops. HortTechnology 3:35-39.

Lee, A., L. Liao, and H. Lo. 2015. Temperature, day length, and cultivar interact to affect the growth and yield of lettuce grown in high tunnels in subtropical regions. HortScience 50:1412-1418.

Munn, D.A. 1992. Comparisons of shredded newspaper and wheat straw as crop mulches. HortTechnology 2:361366.

Patrignani, A. and T.E. Ochsner. 2015. Canopeo: A powerful new tool for measuring fractional green canopy cover. Agron. J. 107:2312-2320. 
Pinamonti, F. 1998. Compost mulch effects on soil fertility, nutritional status and performance of grapevine. Nutr. Cycl. Agroecosyst. 51:239-248.

Roe, N.E., P.J. Stoffella, and H.H. Bryan. 1993. Utilization of MSW compost and other organic mulches on commercial vegetable crops. Compost Sci. Util. 1:7384 .

Salomez, J. and G. Hofman. 2007. A soil temperature/short-wave radiation growth model for butterhead lettuce under protected cultivation in Flanders. J. Plant Nutr. 30:397-410.

Sánchez, E., W.J. Lamont, and M.D. Orzolek. 2008. Newspaper mulches for suppressing weeds for organic high-tunnel cucumber production. HortTechnology 18:154-157.

Sanders, J. 2019. Veusz - A scientific plotting package. 24 Dec. 2019. <https:// veusz.github.io/>.

Schonbeck, M.W. and G.K. Evanylo. 1998a. Effects of mulches on soil properties and tomato production I. Soil temperature, soil moisture and marketable yield. J. Sust. Agr. 13:55-81.
Schonbeck, M.W. and G.K. Evanylo. 1998b. Effects of mulches on soil properties and tomato production II. Plantavailable nitrogen, organic matter input, and tilth-related properties. J. Sust. Agr. 13:83-100.

Skroch, W.A., M.A. Powell, T.E. Bilderback, and P.H. Henry. 1992. Mulches: Durability, aesthetic value, weed control, and temperature. J. Environ. Hort. 10:43-45.

Sinkevičienè, A., D. Jodaugienè, R. Pupaliene, and M. Urbonienè. 2009. The influence of organic mulches on soil properties and crop yield. Agron. Res. $7: 485-491$

Snyder, K., A. Grant, C. Murray, and B. Wolff. 2015. The effects of plastic mulch systems on soil temperature and moisture in central Ontario. HortTechnology 25:162-170.

Steinmetz, Z., C. Wollmann, M. Schaefer, C. Buchmann, J. David, J. Tröger, K. Muñoz, O. Frör, and G.E. Schaumann. 2016. Plastic mulching in agriculture. Trading short-term agronomic benefits for long-term soil degradation. Sci. Total Environ. 550:690-705.
Tarara, J.M. 2000. Microclimate modification with plastic mulch. HortScience 35:169-180.

U.S. Department of Agriculture. 2018. Agricultural refrigerated truck quarterly report. 24 Dec. 2019. <https://www. ams.usda.gov/services/transportationanalysis/agricultural-refrigerated-truckquarterly-datasets $>$.

U.S. Department of Agriculture. 2019. Vegetables 2018 summary. U.S. Dept. Agr., Natl. Agr. Stat. Serv., Washington, DC.

Vargas, P.F., A.C. Zecchini, R.S. Soares, L.D.S. Duarte, and E.H.C. Silva. 2017. Performance of crispy lettuce cultivars in different soil covers. Comun. Sci. 8:514520 .

Valenzuela-Solano, C. and D.M. Crohn. 2006. Are decomposition and $\mathrm{N}$ release from organic mulches determined mainly by their chemical composition? Soil Biol. Biochem. 38:377-384.

Wurr, D.C.E., J.R. Fellows, and G.E.L. Morris. 1981. Studies of the hearting of butterhead lettuce: Temperature effects. J. Hort. Sci. 56:211-218. 